\title{
Money control indicators and investment in Nigeria
}

\author{
${ }^{1}$ Osuji Casmir Chinaemerem, ${ }^{2}$ Nzotta Samuel Mbadike, ${ }^{2}$ Ebiringa \\ Oforegbunam Thaddeus, ${ }^{2}$ Chigbu Emmanuel Ezeji \\ ${ }^{1}$ Department of Accounting, Banking and Finance, Delta State University, \\ Delta State, Nigeria \\ ${ }^{2}$ Department of Management Technology, Federal University of Technology, \\ Imo State, Nigeria
}

\begin{abstract}
This study empirically investigates the impact of money control indicators on investment in Nigeria. This study was necessitated by the apparent failure of the increasing volume of money supply in the Nigerian economy to induce a corresponding increase in investment, output and employment. The study made use of secondary data covering a period of 34 years from 1980 to 2013. Data were sourced from World Bank indicators and CBN Statistical Bulletin. Econometric techniques such as unit root test, co-integration, vector autoregressive model, and impulse response and variance decomposition analysis with granger causality test were used in the data analysis. The findings show that deposit rates impacted positively on investment in Nigeria and private sector borrowing from banks (PSBFB) was significant. These study shows that deposit rates and private sector borrowing from banks were determinants of investment on account of money control indicators. The study, therefore, recommends that government should device monetary measures capable of ensuring stability in deposit rates and private sector borrowing from banks with strict regulations to ensure sustainable money control for investment in Nigeria.
\end{abstract}

Key words: Nigeria, Money, Indicators, Borrowing, Investment

\section{INTRODUCTION}

A major worry that has constantly plagued monetary authorities in Nigeria over time is the variance (more especially when it is negative) that have attended the key macroeconomic policy targets and outcomes of the economy. For instance, in 2008 and 2009, the Central Bank of Nigeria (CBN) set the target of attaining $9 \%$ and $10 \%$ growth in real GDP, but the actual outcomes were $6 \%$ and $7 \%$ respectively. The targeted inflation rates were $10 \%$ for 2007 and $10 \%$ for both 2008 and 2009 while the achievement rates were $12 \%, 9 \%$ and $7 \%$ respectively (CBN 2010). However, when the West-African monetary zone criterion is employed, the target inflation rate of less than $6 \%$ was far from being achieved for the years under consideration (CBN 2010). These are not welcome developments especially when we consider that the situation worsened in the later years those are 2011 and 2012 due to the advent of the global economic crises. Other macroeconomic variables suffered the same fate (Adeboye 2013).

Apart from the worries attending the sub-optimal level of investment in the Nigerian economy, it has not been fully ascertained whether or not the developments in the financial sector or simply the changes in money supply have anything remarkable to do with this investment condition in Nigeria. For instance in the years 2007, 2008, and 2009, the broad money (m2) recorded growth rate of $17 \%, 25 \%$ and $31 \%$ respectively against the targeted growth rates of $15 \%, 27 \%$ and $25 \%$ respectively. The growth rate of bank credit to the private sector were $30 \%, 28 \%, 37 \%$ as against targeted rates of $22 \%, 30 \%$ and $30 \%$ respectively for 2007,2008, and 2009 (Abdel 2014). These growth rates were not, however, sustained in the years of 2010 and 2011 as a result of decrease in investment and general economic activities caused by the global meltdown. The sustainability of the growth rates of domestic credit or domestic investment and even the money supply is not as much as the primary issue at stake in this study as the matter of whether or not the development in the monetary sector can be verified to be responsible for the developments in the general economy.

A critical examination of the Nigerian economy reveals that all the macroeconomic problems which were evident in the economy prior to SAP (that is during the era of Keynesian economic ideas) still persist in 


\section{Osuji Casmir Chinaemerem, Nzotta Samuel Mbadike, Ebiringa Oforegbunam Thaddeus, Chigbu Emmanuel Ezeji \\ Money control indicators and investment in Nigeria}

recent years (Amassoma 2011). This was due to fiscal indiscipline on the part of the government. With the introduction of pure monetarist thinking (that is post SAP era economic ideas) of less government involvement and increased private sector participation in economic management through the policy of privatization in 1988, almost all the sectors of the economy improved in performance as the target of some of the macro economic variables were achieved.

From the observation of the major macroeconomic indicators, it was discovered that prior to 1988, when the economic policies of Keynes dominated the approach in economic management in Nigeria, the performance of the economy was below expectation as most macroeconomic variables could not achieve their set targets. During the period, 1988-2003, the Nigeria economy recorded some positive growth. However, the economy started to walk down the slope in 1991 through 1992. In these periods, the GDP as measured in 1984 factor prices stood at 3.8 percent which compares unfavorable with the 1992 budget projected growth rate of 4.5 percent and the annual growth rate between 1989 and 1991 . The major factor responsible for the decline in economic growth was the domestic policy changes of switching from a public sector driven economic policy to a more market oriented private sector economic policy and inappropriate mix of macroeconomic policy instruments in that respect to achieve desired goals and objectives. In the same vein, other variables perform well such as real GDP growth rate, credit to the domestic economy, credit to the private sector, credit to the government etc. It was understood that this was the period when the monetarists' economic ideas were utilized in the management of the Nigerian economy, which after period of gestation the policies began to yield positive economic results. This study has become necessary considering the volume of monetary transactions going on in Nigeria and the low level of investment in the country.

\section{REVIEW OF RELATED LITERATURE AND APPRAOCH}

A number of approaches have attempted to define money and the compositions of a country's money stock. Four approaches have been distinguished, namely, the conventional approach, the Chicago approach, the Gurley and Shaw approach, and the Central Bank approach (Ezirim, 2005).

\section{THE CONVENTIONAL APPROACH}

The Conventional Approach views money from a functional standpoint, i.e. in the light of what money uniquely does? Accordingly, money has been seen as "a generalized means of purchasing power that is acceptable as payment for goods and services" (Copper and Fraser, 1990). Thus, as the common denominator for economic and business transactions, money mediates between vast number of goods and services transacted in the community" (Chew 2009). Thus, what constitute the money stock of any country would be those mediums that facilitate readily the exchange mechanism and command general acceptability (DD) created by commercial banks. In Nigeria, this is defined as MI.

Thus, $\mathrm{M} 1=\mathrm{C}+\mathrm{DD}$

It is of note that in the Central Bank of Nigeria's definition, M1 is the currency outside banks plus privately held demand deposits with the commercial banks and the Central Bank.

\section{THE CHICAGO APPROACH}

The Second approach is that championed by the monetary theorists of Chicago University. As propounded by one of their leading spokesmen, Milton Friedman, "money is a temporary abode of purchasing power". The basic argument is that, since there seems to be an imperfect synchronization between income receipts and expenditure streams over time, then money not only function as a medium of exchange, but also as a temporary store of purchasing power. By implication, the total money stock must not be restricted to $M 1$ as expressed above, but must include any other asset that commands liquidity akin, or near to currency. These other assets have fixed interest-bearing time deposits of commercial banks. This originated the M2 definition of total money stock. Therefore,

$$
\mathrm{M} 2=\mathrm{M} 1+\mathrm{TD} 1
$$

Where $M 1$ = as defined above

TD1 = Fixed interest bearing time deposits of commercial banks.

In Nigeria, there is a little variation, not in principle but in content, of what has been described as M2. For the Central Bank of Nigeria the M2 definition of money includes Ml plus quasi money defined as savings and time deposits with commercial banks, plus total liability of merchant banks. In which case the modified M2 can be expressed as

$\mathrm{M} 2=\mathrm{M} 1+\mathrm{TD},+\mathrm{SD} 1-\mathrm{TDL}$

Where, $M 1$ and TD1 = as defined above 
SD1 = Savings Deposits with Commercial Banks;

TDL $=$ Total Deposit Liabilities of Merchant Banks.

It is also of note that prior to 1988 , quasi money did not include the deposit liabilities of merchant banks.

\section{THE GURLEY AND SHAW APPROACH}

The Gurley and Shaw approach introduced another dimension to the definition of money and money supply. Apart from broadening the content of the money stock they added a cardinal element of assigning weights to the various components. Accordingly, they define currency (C) and demand deposits (DD) as claims against financial intermediaries (central bank and commercial banks, in this case. However, they do not constitute the intermediaries, which are close substitutes for money. Such close substitutes include, according to the approach, commercial banks' time deposits, credit institutions' shares, bonds, etc. They argue that all these are viable alternatives to liquid stores of value to the public. Thus, the money stock is broadened as expressed below:

$$
\begin{aligned}
& \mathrm{M} 3=\mathrm{C}+\mathrm{DD}+\mathrm{TD} 1+\mathrm{SD} 1+\mathrm{S}+\mathrm{B} \\
& \text { Where, } \\
& \mathrm{S}=\text { Share of credit institutions; } \\
& \mathrm{B}=\text { Bonds. }
\end{aligned}
$$

\section{THE CENTRAL BANK APPROACH}

Finally, we have the widest view of money as through it were one and the same thing as credit funds lent to borrowers. This view has been favoured by central banks of most developed countries, which earned it the name, the central bank approach. The Federal Reserve Systems of the United States seems to favour this viewpoint in their definition of money which comprises M3 plus non-bank public holding of U.S. savings bonds, short- term U.S. Treasury securities, commercial papers and bankers' acceptance, net of money market mutual holdings of these assets.

Thus, we can define $\mathrm{M} 4$ as expressed below.

$$
\begin{aligned}
& \mathrm{M} 4=\mathrm{M} 3+\mathrm{SB}+\mathrm{TS}+\mathrm{CP}+\mathrm{BA}+\mathrm{M} 3 \mathrm{H} \\
& \text { Where } \mathrm{SB}=\text { Savings bonds; } \\
& \mathrm{TS}=\text { Short-term treasury securities; } \\
& \mathrm{CP}=\text { Commercial papers; } \\
& \mathrm{BA}=\text { Bankers' Acceptances; } \\
& \mathrm{M} 3 \mathrm{H}=\text { Net of Money market mutual holdings of assets. }
\end{aligned}
$$

The underlying reasoning for this broadest approach is the existence of a similarity, the proponents' claim, between money and other means of financial purchases.

From the M4 definition above, MI is uniquely identified with elaborate credit instruments from a different source.

\section{RESEARCH METHODOLOGY}

This section explains the pattern and methods the research study adopted. In this section, highlight of the various techniques employed in the study are stated to enable the relevant data analysis. Research design, population/sample size, sampling techniques, data collection method, modeling procedures, estimation of model procedures and method of data analysis are explained in details.

\section{MODELLING PROCEDURE}

The study deals on the classifications based on the similarity of macroeconomic variables within the span of time of 34 years to enable clear understanding of the economic behavior pattern of the countries, hence, performing comparative studies. Several studies may have been conducted or ongoing (see details in the literature). The model specified in Carlson (1978), enmeshed two income models, one with money supply changes as the critical independent variable, and the other with government expenditure as the independent variable.

The two models are: The two models are:

$$
\begin{aligned}
& Y_{t}=\alpha+\beta_{0}+M_{t}+\beta_{1} M_{t-1}+\beta_{2} M_{t-2}+\beta_{3} M_{t-3}+\beta_{4} M_{t-4}+U_{i t} \\
& =\beta_{0}+\sum_{i=0}^{4} \beta_{i} M_{t_{i}-1}+\mu_{i t}
\end{aligned}
$$




$$
\begin{aligned}
& Y_{t}=b+\lambda_{0}+E_{t}+\lambda_{1} E_{t-1}+\lambda_{2} E_{t-2}+\lambda_{3} E_{t-3}+\lambda_{4} E_{t-4}+U_{s t} \\
& =a+\sum_{i=0}^{4} \lambda_{i} E_{t_{i}-1}+U_{i t}
\end{aligned}
$$

Where:

$Y_{t}=$ rate of growth in nominal GDP at time t.

$M=$ rate of growth in money supply (M1) at time $t$.

$E_{t}=$ rate of growth in full, or high employment government expenditure at time t. Enmeshing the two models we have:

$$
Y_{t}=\beta_{0}+\sum_{i=0}^{4} \beta_{t} M_{t-1}+\sum_{i=0}^{4} \lambda_{i t} E_{t-1}+U_{3 t}
$$

\section{Nzotta and Okereke's Model}

Nzotta and Okereke (2009) reformulated the model used by Nnanna and Dogo (1998) in their investigation of the financial deepening function in pre and post financial reform periods in Nigeria. In Nnanna and Dogo (1998) specifications, six explanatory variables were used in investigating financial deepening. However in Nzotta and Okereke (2009) model Financial Deepening (M2/GDP) depends on, Financial Savings/GDP ratio (FS/DGP) Private Sector Credit/GDP (PSC/GDP) value of Cheques Cleared to GDP ratio (CHQ/GDP), value of Cheques Cleared to Money Supply (CHQ/MS2) the Rate of Inflation (INFLA), Prime lending rates (PLRA) the Intermediation ratio i.e. Currency outside Banks to Money Supply (COB/MS2) and the Dummy.

This study chooses to review Nzotta and Okereke's Model robust as the above specification and modify it with the introduction of macroeconomic variables. The state of money neutrality has changed considerably in the developing world and effort is required to specify operational parameters different from the studies as explained in the literature.

\section{MODEL SPECIFICATION}

The functional model is specified to measure the impact of monetary control indicators on investment using the money control model. The model is transformed in log-linear and structured to establish the relationship between the model and investment in Nigeria. The model is specified based on the Keynesian theory of investment that emphasized the control role of investment in the theory of aggregate output and employment.

\section{Money Control Model (MCM)}

$$
\begin{aligned}
\operatorname{LnTotINV}_{c t-1}=\alpha_{0}+\alpha_{1} \sum_{i=1}^{n} \operatorname{LnGBFB} B_{c t-1} & \alpha_{2} \sum_{i=1}^{n} \operatorname{LnPSBFB}_{c t-1}+\alpha_{3} \sum_{i=1}^{n} \operatorname{LnLR}_{c t-1} \\
& +\alpha_{3} \sum_{i=1}^{n} \operatorname{LnDR}_{c t-1}+\operatorname{Var}\left(\beta_{i}\right)+\varepsilon_{t-1}
\end{aligned}
$$

Where

LnGBFB = Log government borrowing from banks;

LnLR = Log lending rates;

LnDr = Log deposit rates;

Ln PSBFB = Log private sector borrowing from banks.

\section{SOURCES AND METHOD OF DATA ANALYSIS}

Data for this study were attained from secondary sources via world bank indicators and CBN statistical bulletin. This estimation period is from 1980 to 2014 . 


\section{EMPIRICAL DATA ANALYSIS AND DISCUSSION OF RESULT}

This section discusses the empirical analysis of the data for the study in tables below and discussed as follows:

Table 1: Unit Root Test Result

\begin{tabular}{|c|c|c|c|c|c|c|}
\hline Variable & Order & ADF & $\begin{array}{l}\text { Critical } \\
\text { value }\end{array}$ & $\begin{array}{l}\text { ADF }>\text { Critical } \\
\text { Value }\end{array}$ & Conclusion & At \\
\hline LnTotINV & $\mathrm{I}(0)$ & -24.234 & -2.9540 & No unit root & Stationary & Level \\
\hline LnGBFB & $\mathrm{I}(1)$ & -5.1539 & -2.9604 & No unit root & Stationary & 1st diff. \\
\hline LnPSBFB & $\mathrm{I}(1)$ & -4.5984 & -2.9571 & No unit root & Stationary & 1st diff. \\
\hline LnLR & $\mathrm{I}(1)$ & -8.1924 & -2.9604 & No unit root & Stationary & 1st diff. \\
\hline LnDR & $\mathrm{I}(1)$ & -5.6326 & -2.9571 & No unit root & Stationary & 1st diff. \\
\hline
\end{tabular}

Source: E-Views7.1 Result Summary Output, 2014

The result of the unit root test above summarizes the unit root test of the variables to examine the stationarity of variables over time. Augmented Dickey Fuller Test (ADF-Test) results confirmed that Total Investment (LnTotINV), stationary at level $\mathrm{I}(0)$ since the ADF values are far greater than the critical values at $5 \%$ level. In addition, government borrowing from the bank (LnGBFB), private sector borrowing from the bank (LnPSBFB), lending rate (LnLR) and deposit rate (LnDR) are stationary at order $1 \mathrm{I}(1)$ These results of unit root tests of each variable suggest that there is no presence of unit root as the ADF values are greater than the critical value at $5 \%$. All the variables are stationary. Therefore, there is strong evidence of no unit root in the total investment variable.

Table 2: Johansen Co integration Result

Unrestricted Co-integration Rank Test (Trace)

\begin{tabular}{ccccc}
\hline \hline $\begin{array}{c}\text { Hypothesized } \\
\text { No. of CE(s) }\end{array}$ & Eigen value & $\begin{array}{l}\text { Trace } \\
\text { Statistic }\end{array}$ & $\begin{array}{l}0.05 \\
\text { Critical Value }\end{array}$ & Prob.** \\
\hline \hline None * & 0.684063 & 92.54554 & 69.81889 & 0.0003 \\
At most 1 * & 0.621844 & 56.82700 & 47.85613 & 0.0057 \\
At most 2 & 0.413983 & 26.68106 & 29.79707 & 0.1097 \\
At most 3 & 0.258796 & 10.11446 & 15.49471 & 0.2720 \\
At most 4 & 0.026438 & 0.830606 & 3.841466 & 0.3621 \\
\hline \hline
\end{tabular}

Trace test indicates 2 co-integrating eqn(s) at the 0.05 level

$*$ denotes rejection of the hypothesis at the 0.05 level

$* *$ MacKinnon-Haug-Michelis (1999) p-values

Johansen test of co integration tables above suggest that the maximum eigenvalue and trace tests statistics (L.R) of money control indicators of total investment in Nigeria have values greater than the critical values at 1 and 5 percent levels of significance at most $1^{*}$. Therefore, the null hypotheses of no co-integrating vectors are rejected. Hence, there is co integration with at least 2 co integrating equations. Therefore, there is strong evidence of long run equilibrium relationship between the money control variables and the total investments in Nigeria.

Table 3: VAR Model Relative Statistics of Money Control Model of Investment

\begin{tabular}{|c|c|c|c|c|c|c|}
\hline \multicolumn{7}{|c|}{ Relative Statistics } \\
\hline $\begin{array}{l}\text { MCM } \\
\text { Variables }\end{array}$ & Coeff. $(\beta)$ & $\operatorname{sE}(\beta)$ & T-statistic & $\begin{array}{l}\text { '2-t' sig. } \\
\text { at } 5 \%\end{array}$ & $\begin{array}{l}\text { T-stat >'2-t' sig. } \\
\text { at } 5 \%\end{array}$ & Conclusion \\
\hline LnGBFB & 0.0170 & 0.0439 & 0.3872 & '2-t' sig. & It is not significant & \\
\hline LnPSBFB & 0.7715 & 0.4448 & 1.7352 & '2-t' sig. & It is significant & $* *$ \\
\hline LnLR & 0.3847 & 1.9704 & 0.1952 & '2-t'sig. & It is not significant & \\
\hline LnDR & 1.2336 & 1.2002 & 1.0279 & '2-t' sig. & It is not significant & \\
\hline
\end{tabular}

$* *$ Sig. if F-stat $<2$ - $\mathrm{t}^{\prime}$ sig., Source: E-Views statistical package version 7 


\section{Osuji Casmir Chinaemerem, Nzotta Samuel Mbadike, Ebiringa Oforegbunam Thaddeus, Chigbu Emmanuel Ezeji \\ Money control indicators and investment in Nigeria}

From the relative statistics results of the money control variables model (MCM) of investment, estimated values of the coefficient of government borrowing from bank (LnGBFB) shows that the estimate of $\beta$ is 0.017 implying that there is a positive relationship between the LnGBFB and total investment (LnTotINV) in Nigeria. This further suggests that a unit change in LnGBFB will result in 0.017 increases in total investment (LnTotINV). The estimate of $\beta_{2}$ is 0.7715 which is the coefficient value of private sector borrowing from bank (LnPSBFB) shows that there is a direct impact between the private sector borrowing from bank (LnPSBFB) and investment (INV). Therefore, unit change in private sector borrowing from bank (LnPSBFB) results in 0.77 increases in investment (INV).

The estimate of $\beta_{3}$ is 0.3847 is the coefficient value of lending rate ( $\left.L n L R\right)$. This implies that there is a direct relationship between the lending rate (LnLR) and foreign investment (LnFI). This further means that a unit change in lending rate (LnLR) results in 0.38 increases in Investment (INV). For deposit rate indicator of total investment in Nigeria, the result shows that there is direct impact of deposit rate (LnDR) on total investment. The estimate of $\beta_{4}$ is 1.2336 which is the coefficient value of deposit rate (LnDR). This implies that there is any change in deposit rate (LnDR) will impact on total investment (LnTotINV) by 1.23. The value of T-statistics for the coefficient of government borrowing from bank (LnGBFB), private sector borrowing from bank (LnPSBFB), lending rate (LnLR) and deposit rate (LnDR) have values of $0.38,1.74,0.19$ and 1.02 of t-statistic respectively. These result reveals that that the values of t-ratio for the estimates lending rate ( $L n L R)$ is greater than or equal to the ' 2 - $t$ ' significant rule of thumb. This implies that lending rate ( $L n L R)$ has statistical significant relationship with the total investment in Nigeria. Indicators such as government borrowing from bank (LnGBFB), private sector borrowing from bank (LnPSBFB) and deposit rate (LnDR) have $t$-values less than the ' 2 - $t$ ' significant rule of thumb. These indicators of money control model of total investment are not statistically significant. Therefore the null hypothesis is not rejected.

Table 4: Granger Causality Tests

\begin{tabular}{lccc}
\hline \multicolumn{1}{c}{ Pairwise Granger Causality Tests } & & & \\
\hline \hline & Obs & F-Statistic & Prob. \\
\hline LNGBFB does not Granger Cause LNTOTINV & 32 & 3.02268 & 0.0654 \\
LNTOTINV does not Granger Cause LNGBFB & & 1.86388 & 0.1745 \\
\hline \hline LNPSBFB does not Granger Cause LNTOTINV & 32 & 4.54660 & 0.0199 \\
LNTOTINV does not Granger Cause LNPSBFB & & 0.03286 & 0.9677 \\
\hline \hline & & & \\
\hline LNLR does not Granger Cause LNTOTINV & 32 & 0.26625 & 0.7682 \\
LNTOTINV does not Granger Cause LNLR & & 0.43469 & 0.6519 \\
\hline \hline & 32 & 3.56742 & 0.0422 \\
\hline LNDR does not Granger Cause LNTOTINV & 3.44558 & 0.0465 \\
\hline LNTOTINV does not Granger Cause LNDR & & 3 & \\
\hline
\end{tabular}

From the table $4 \mathrm{a}$ above, the test results of granger causality reveals that government borrowing from bank (LnGBFB) does not granger cause total investment and total investment does not granger cause government borrowing from bank (LnGBFB). Private sector borrowing from bank (LnPSBFB) has unidirectional causal relationship with the total investment but total investment does not granger cause private sector borrowing from bank (LnPSBFB). However, both deposit rate (LnDR) and total investment (LnTotINV) granger cause each other. Hence, there is evidence of long run causal relationship between the deposit rate and total investment in Nigeria. Lending rate (LnLR) and total investment have no causal relationship. Therefore no long run causality existed between the variables at $5 \%$ significant level. 
Money control indicators and investment in Nigeria

Table 5: Money Control Model of Total Investment Variance Decomposition of LNTOTINV:

\begin{tabular}{ccccccc}
\hline \hline & & & & & \\
Period & S.E. & LNTOTINV & LNGBFB & LNPSBFB & LNLR & LNDR \\
\hline \hline 1 & 1.529591 & 100.0000 & 0.000000 & 0.000000 & 0.000000 & 0.000000 \\
2 & 1.598562 & 92.31832 & 2.394527 & 1.229164 & 0.443317 & 3.614674 \\
3 & 1.627566 & 89.17010 & 4.104613 & 1.879888 & 1.296619 & 3.548784 \\
4 & 1.632249 & 88.93439 & 4.161044 & 1.869202 & 1.489964 & 3.545403 \\
5 & 1.634661 & 88.70185 & 4.220402 & 1.946377 & 1.591891 & 3.539475 \\
6 & 1.636638 & 88.48953 & 4.265314 & 2.118359 & 1.592385 & 3.534414 \\
7 & 1.638659 & 88.32789 & 4.275717 & 2.280758 & 1.589822 & 3.525818 \\
8 & 1.640375 & 88.16208 & 4.266874 & 2.465848 & 1.586646 & 3.518550 \\
9 & 1.642054 & 87.99806 & 4.260112 & 2.639060 & 1.591395 & 3.511371 \\
10 & 1.643942 & 87.82461 & 4.250811 & 2.809459 & 1.611506 & 3.503614 \\
\hline \hline
\end{tabular}

Money control model indicators for total investment in Nigeria shows that in the short run, that is quarter 3, shock to total investment (LnTotINV) account for $89.17 \%$ variance of the fluctuation in LnTotINV, that is, own shock. Shock to government borrowing from bank (LnGBFB) causes $4.12 \%$ fluctuation in LnTotINV. A shock to private sector borrowing from bank (LnPSBFB) accounts for $1.88 \%$ fluctuation in investment Shock to lending rate (LnLR) causes $1.29 \%$ fluctuation in LnTotINV. Shock to deposit rate (LnDR) causes $3.55 \%$ fluctuation in LnTotINV. On the whole, the shock causes $100 \%$ in the short run in quarter 3 with total investment having the highest impact on itself (own shock).

In the long run, that is quarter 10 , innovation to LnTotINV accounts for $87.82 \%$ variation in the fluctuation in LnTotINV (own shock). Shock to interest rate (SINT) can cause 31.13\% fluctuation in investment. Any shock to government borrowing from bank (LnGBFB), private sector borrowing from bank (LnPSBFB), lending rate (LnLR) and deposit rate (LnDR) cause $4.25 \%, 2.81 \%, 1.61 \%$ and $3.50 \%$ variance in the fluctuation in total investment (LnTotINV). Total innovation of indicators contributing to total investment in the long run based on the money control model are government borrowing from bank (LnGBFB) and deposit rate (LnDR) in quarter 10.
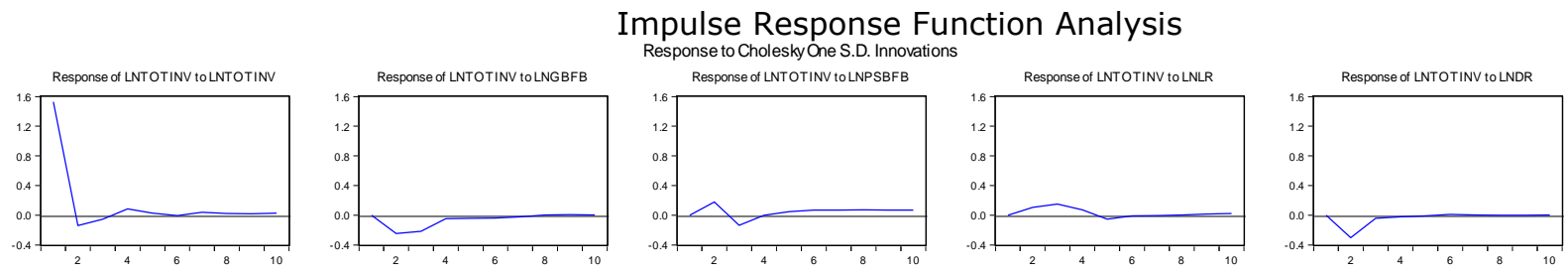

One STD to total investment (LnTotINV), investment will decline positively after 3 periods, rises after 4 period and become stable between period 5 through to 7 then becomes positive after 10 periods. One STD to government borrowing from bank (LnGBFB), total investment (INV) is stable between 1 and 2 period and decrease positively after 3 to 5 periods then becomes positively increase after 10 periods. If interest goes up, investment in Nigeria will be reacting positively unstable. One STD to private sector borrowing from bank (LnPSBFB), LnTotINV will be positive after 3 period and negative after 10 periods. If LnPSBFB goes up, investment will be reacting relatively stable after period 10 . One STD to lending rate (LnLR), LnTotINV will be positive after 3 period and fell after 4 period and become positively stable after 10 periods. A shock to deposit rate (LnDR).

\section{CONCLUSION}

In this study, analysis of unit root to establish stationarity nature of various model indicators of investment are carried out and the order integration examined among government borrowing from banks (LnGBFB), Lending rate (LnDR), Private sector borrowing from banks (LnPSBFB), deposit rate (LnDR) and Total Investment (LNTotINV). There is a bi-directional causal relationship between deposit rate and investment in Nigeria. Therefore, the performance of investment is found to be influenced by private sector borrowing from banks (LnPSBFB and deposit rates (LnDR). The results support the theoretical contention and give strong support to the hypothesis that the total money supply is terms of deposit rated and private sector borrowing contributes to total investment inflows is most developed and developing countries by the literature. 


\section{REFERENCES}

- AbdelKoder, C. (2014). Extent of Credit Decline to the Private Sector in Egypt. International Journal of Business and Economics Perspective, Volume 4, 211-214.

- Adeboye, B.C (2013). Long run Relationship Between Budget Deficit and Economic Growth. London, Macmillian Press.

- Amassoma, P. (2011). Effect of Monetary Policy on Macroeconomic variables in Nigeria. Journal of Accounting and Finance. Volume 3(2) 68-72.

- Asian, O. and Korap, L. (2007). Testing Quantity Theory of Money for the Turkish Economy. BDDK Bankacthk ye Finansal Plyasalar; Cilt: 1, Say>: 2;. 93 - 109.

- Central Bank of Nigeria (2011). Central Bank of Nigeria Annual Reports and Statement of Account for the year ended 31st December 2010. Abuja, CBN Press.

- Chew, M. S. (2009). The Reeded edge and the Phillips curve: money neutrality, common knowledge, and subjective believes. Journal of Economic Theory. Volume 2(2) 130-144.

- Cooper, K. and Fresar, D.R. (1990). The Financial Market-place New York.Addison-Wesley Publishing Company

- Ezirim, B.C. (2005). Finance Dynamics: Principles, Techniques and Applications. Port Harcourt: Markowitz Center for Research and Development.

- Federal Reserve Bank of St. Louis (1982). Revised Form of St. Louis Model, Review, Federal Reserve Bank of St. Louis, May, P. 14.

- Friedman, M. (1970). Counter Revolution in Monetary Theory. Chicago: University of Chicago Press.

- Gurley, J. G. and Shaw, E, S, (1960). Money in a Theory of Finance". Washington D. C.: Brooking Institution.

- Keynes, J. M. (1936). The General Theory of Employment, Interest, and Money. London: T Macmillan Press Ltd.

- Mises, L. (1945). The Non-Neutrality of Money. Paper Delivered to the New York City Economics Club in New York.

- Nnanna, O.J and Dogo M. (2008). Structural Reform Monetary Policy and Financial Deepening. The Nigerian Experience Economic and Financial Review. Vol. 36(2) 1-29.

- Nzotta S.M and Okereke E. (2009). Monetary Policy and Financial Deepening. African Journal of Accounting, Econometrics, Finance and Banking Research. Vol. 5 (5) 50-63. 